\section{Cinco imagens e múltiplos olhares: 'descobertas' sobre os indios do Brasil e a fotografia do século XIX}

\section{Five images and} multiple views: 'discoveries' about Brazilian indians and

\section{nineteenth-century photography}

Este trabalho foi publicado na revista Histoire et Sociétés de l'Amerique Latine, (n⿳⺈ 11-1, Paris, Harmattan/Aleph, 2000)
MOREL, M.: 'Cinco imagens e múltiplos olhares: 'descobertas' sobre os índios do Brasil e a fotografia do século XIX'. História, Ciências, Saúde-Manguinbos, vol. VIII (suplemento), 1039-58, 2001.

Análise histórica e iconográfica tomando como referência a série de daguerreótipos (guardada no Museu do Homem, na França) de dois índios Botocudo, feita por E. Thiesson em Paris, 1844, tratada a partir de uma pluralidade de olhares: os dos homens da ciência do século XIX, do próprio autor na condição de historiador e dos atuais Krenak, pertencentes ao mesmo grupo etnolingüístico fotografado. Tais daguerreótipos estão entre os primeiros registros fotográficos de índios e trazem à tona as articulações entre ciência, imagem, guerra e formação da nacionalidade.

PALAVRAS-CHAVE: história indígena, Botocudo, história da fotografia, Brasil, história do século XIX.

MOREL, M.: 'Five images and multiple views: 'discoveries' about Brazilian indians and nineteenth-century photography'.

História, Ciências, Saúde-Manguinbos, vol. VIII (supplement), 1039-58, 2001.

This article is a historical and iconographic analysis of different views on several 1844 daguerreotypes of two Botocudo indians, taken by E. Thiesson in Paris in 1844 and kept at Musée de l'Homme in France at present. They correspond to the different perspectives of nineteenth-century scientists, of the author bimself as a bistorian and of present-day Krenak, near kin to Botocudo. These daguerreotypes are some of the first photographic records of Brazilian indians and make evident the relations between science, image, war and the construction of nationality.

KEYWORDS: indian History, Botocudo, History of photography, Brazil, nineteenth-century bistory.
Marcos Morel

Rua Araújo Lima, 169/301 A

20541-050 Rio de Janeiro — RJ Brasil

mmorel@uol.com.br 
${ }^{1}$ Os daguerreótipos pertencem à Coleção Jacquart e têm os seguintes códices: D-801317, D-80-1318, D-801319; D-80-1315 e E-791396 (repetidos); E-791397 e D-80-1320 (repetidos). Em 1995 estas imagens não constavam de nenhum dos fichários do Musée de l'Homme disponíveis ao público, embora existissem referências a elas em documentos do século XIX. Diante do meu pedido à instituição, não tive dificuldade em consultá-las e reproduzilas. Dois destes daguerreótipos já haviam sido reproduzidos em Frizot (1994, p. 268) e um deles em Garrigues (1991).
As fotografias pulsam com os movimentos de outrora: como um passante, perambulo em todas as direções, de uma margem a outra, para dar a conhecer ao vivente aquilo que não desapareceu totalmente e seguir o caminho com ele (Arlette Farge, 2000, p. 9).

$\mathrm{O}$ encontro entre os índios e a fotografia do século XIX tem qualquer coisa de impressionante. Trata-se de campo de análise instigante e ainda pouco revolvido, que envolve abordagem interdisciplinar englobando a dimensão iconográfica e remete ao contato entre uma tecnologia surgida numa Europa tão marcada pela preocupação com o progresso com populações que viviam em tribos. A diferença de culturas e a pluralidade de tempos coexistem num mesmo momento histórico. Uma 'leitura' destas primeiras fotos nos coloca diante da relação entre guerra, expansão da civilização ocidental de matriz européia e imagem. O instante eternizado remete a um momento de passagem crucial para as transformações da civilização européia e seu mundo da ciência, também para a trajetória histórica das tribos indígenas enfocadas pelas lentes e para a história de vida dos que foram fotografados, dimensões como que unidas por meio da fixação das imagens.

O objetivo deste artigo é tratar de uma série de sete daguerreótipos (cinco imagens, pois duas são repetidas) produzida na França em 1844 por E. Thiesson e que se encontra na Photothèque du Musée de l'Homme, Paris, retratando um homem e uma mulher Botocudo (Naknyanúk) trazidos do Brasil. ${ }^{1}$ Estas fotografias engendram 'descobertas' que se entrecruzam sob diferentes olhares. Tratarei de análise histórica: das visões dos homens de ciência do século XIX (que não eram homogêneas), explicitarei minha própria percepção (partindo da condição de historiador) diante destas imagens e também como os atuais índios Krenak (pertencentes ao mesmo grupo etnolingüístico dos que foram fotografados) vêem tais ícones.

Estes daguerreótipos são, talvez, as primeiras fotografias de índios feitas no mundo. Instaurar este tipo de primazia não é importante: outras fotos de seres humanos classificados como 'índios' podem ter sido tiradas antes e isso não alteraria em nada a dimensão destas imagens naquele contexto e as interpretações que podemos fazer delas hoje. De qualquer maneira, vale ressaltar o pioneirismo (sem nenhum sentido valorativo) da realização. Sabe-se que a invenção da fotografia foi anunciada oficialmente em 1839 no Institut de France. Dois anos depois, os irmãos Bisson registraram em daguerreótipos uma série de duzentas litogravuras de indígenas da Nova Zelândia, ou seja, transpuseram para a nova técnica retratos feitos de forma tradicional (Starl, 1994, p. 47). Em 1847, o chefe índio Watchful Fox teve seu retrato em daguerreótipo feito por T. M. Easterly, dos Estados Unidos (Oppitz, 1992, pp. 742-3; Scherer, 1996). Ainda neste domínio, hoje chamado de 'etnofotografia', sabe-se de outros daguerreótipos: do esqueleto de um 
${ }^{2}$ Marc Ferrez, série de 12 daguerreótipos tirados no sul da Bahia em 1876 durante a Expedição Hartt (Souvenirs de Voyage, códices G 61310 até $\mathrm{G} 61321$ Bibliothèque Nationale de France)
${ }^{3}$ Uma síntese do estado da discussão sobre as relações entre história, etnologia e antropologia encontra-se em Bonte e Izard (1992). homem negro em 1847, do crânio de um árabe na mesma época e do rosto de Caesar, o último escravo negro de Nova York, em 1850 (Starl, op. cit., p. 43; Frizot, 1994, p. 267). Fotografias de esquimós estão entre as primeiras a serem incorporadas à coleção do então Muséum d'Histoire Naturelle de Paris, mas não há informações sobre a data em que foram realizadas (Conduché, 1858). As fotos mais antigas que se conhece de índios feitas no território do Brasil são de 1865, de autoria do suíço August Frisch, que viajou ao longo do rio Amazonas (Freire, 1996, p. 401). Da mesma forma são conhecidos os daguerreótipos de outros índios Botocudo na Bahia, pelo fotógrafo francês Marc Ferrez, em 1876, também dentro da aproximação entre fotografia e antropometria. ${ }^{2}$

Em que circunstâncias ocorreu o encontro entre os índios do Brasil e a fotografia, que resultou nos daguerreótipos de 1844?

\section{A 'descoberta' dos índios pela fotografia: a ciência volta à carga}

A fotografia recém-nascida trazia uma dimensão de lazer, consumismo, modismo tecnológico, empolgação pela novidade, mas sobretudo de possibilidade de 'reprodução do real'. E aí tinha usos mais 'sérios'. Ligou-se estreitamente à medicina e ao controle da criminalidade. Doentes mentais, prisioneiros, pessoas com deformidades físicas e povos considerados exóticos (ex-optico, fora da ótica) passaram a ser enquadrados pelas lentes implacáveis. A fotografia tornou-se uma forma de conhecimento, fixação e controle dos corpos através da imagem (Frizot, op. cit. pp. 259-71).

A Cidade-Luz vivia os tempos da Monarquia de Julho, sob a efígie do 'rei cidadão', onde ideólogos e doutrinários do liberalismo buscavam fortalecer o primado das classes médias na sociedade francesa. No Jardin de Plantes (próximo ao Quartier Latin e à Sorbonne), o Muséum abrigava esqueletos humanos, espécies animais, vegetais e minerais em torno de agradáveis e bem cuidados jardins, onde estavam as casas que (ainda em plena atividade, como até hoje) haviam servido de residência e gabinete de trabalho para Buffon, Lamarck e outros criadores da história natural. E no mesmo recinto do anúncio da invenção da fotografia, cinco anos depois, estes daguerreótipos estavam no cerne do debate de uma disciplina que se transformava, inclusive metodologicamente: a história natural, marcada pela Ilustração do século XVIII, privilegiava o 'desenho científico', enquanto que a emergente antropologia física se impregnaria do evolucionismo e passaria a usar a foto. ${ }^{3}$

No caso destes daguerreótipos há uma relação entre ciência, guerra de extermínio étnico e escravidão. As tribos de botocudos viviam um contato de três séculos com os movimentos de colonização no território brasileiro e havia um forte componente bélico nesta relação, mesmo que as dimensões de diálogo, negociações e miscigenação estivessem também presentes de maneira clara, fazendo parte deste encontro mais 
${ }^{4}$ Estes grupos, nomeados de Aimoré até o século XVIII, durante o século XIX eram chamados de Botocudo (possuíam diferentes nomes locais, como Guturack, Naknyanúk, Pojichá etc.) e desde princípios do século XX são conhecidos como Krenak. Vistos pelos colonizadores como temíveis guerreiros, ocupavam inicialmente extensa faixa do território incluindo partes das províncias da Bahia, Minas Gerais e Espírito Santo e durante quatro séculos ofereceram resistência e infligiram sérias derrotas às tentativas de colonização e conquista. Pertencem ao grupo etnolingüístico MacroJê. Para uma síntese histórica e antropológica sobre estes grupos, ver Paraíso (1998, pp. 41330). Consultar também o trabalho de Mattos (1996), que aprofunda o estudo entre os atuais índios.

${ }^{5} \mathrm{Na}$ verdade, haviam se passado 14 anos e não 18. Existe ainda uma imprecisão cronológica: como se explica que os retratos feitos $(\mathrm{e}$

datados) em 1844 tivessem sido analisados na Academia de Paris no verão de 1843 ? Trata-se de questão ainda sem resposta. que secular. Era uma guerra de longa duração. E na década de 1840 esta guerra era conjugada no presente: ainda resistiam e sofriam verdadeiro genocídio por parte da sociedade brasileira; havia tráfico de escravos desta tribo na província de Minas Gerais em benefício de obras públicas, construção de estradas e trabalho doméstico.

Ainda que a legislação e o discurso oficial da monarquia brasileira não acatassem a escravidão indígena e valorizassem estas populações como objetos de estudos científicos, o que ocorria ao mesmo tempo era que, no contato direto com proprietários rurais e autoridades locais, predominavam o preconceito e a violência em relação a tais índios. Sobretudo levando-se em conta que suas terras situavam-se numa região próspera e com reservas de riquezas minerais exploradas por firmas britânicas. A sede do progresso cobiçava estas faixas de florestas tropicais próximas ao litoral brasileiro conhecidas hoje como Mata Atlântica, da qual resta apenas $5 \%$ da superfície original. ${ }^{4}$ Neste contexto os dois índios foram levados a Paris em 1843 por um certo Marcus Porte.

As placas registrando os corpos dos dois índios causaram viva impressão, inclusive pela qualidade técnica. "Desde essa época, 18 anos se passaram, nada se fez de mais puro, mais límpido, mais franco", exclamava com certa volúpia visual um crítico da arte fotográfica da época (Conduché, 1858). ${ }^{5}$ Apesar de toda carga de objetividade típica do século XIX, a apreciação destas imagens (do ponto de vista estético, técnico ou científico) não era em geral vinculada às condições de vida das pessoas fotografadas.

Antes mesmo de serem fotografados, o homem e a mulher trazidos das selvas do Brasil ganharam notoriedade graças ao debate que ocupou parte da sessão de verão do Institut de France de 1843 (Serres, 1845-46, pp. 7-11; Saint-Hilaire, 1845-46, pp. 4-10). O membro da Academia encarregado de expor o tema foi Serres, que fala em seu relatório destes dois Botocudo. A principal preocupação do cientista diante dos índios foi realizar cuidadosas medidas antropométricas, o que já indica sua filiação intelectual. Altura, dimensão das partes do corpo, os dois índios foram escrupulosamente esquadrinhados. Serres não esqueceu a cor da pele, fator tão importante para uma classificação do tipo racial, qualificando-a como marrom-avermelhada (brun rougeâtre). De posse deste material (medidas antropométricas e observações físicas), o acadêmico preparou seu relatório lido na sessão.

Ao apresentar suas conclusões para o plenário da Academia de Ciências, Serres aprimorou suas interpretações. Buscou fazer uma análise comparativa dos Botocudo com os índios Iawoa, dos Estados Unidos da América do Norte, e para isso utilizou as obras do príncipe Maximilien de Wied-Neuwied (1821-22), que estudara os índios dos dois hemisférios. Serres selecionou trechos das observações do viajante prussiano sobre a relação entre marido e mulher nas referidas tribos. A partir dos exemplos colhidos por Wied-Neuwied, Serres conclui que o Botocudo 
${ }^{6}$ A organização da antropologia como campo de saber separado da zoologia estava se firmando em meados do século XIX. Por exemplo, a cadeira de antropologia foi fundada no Muséum d'Histoire Naturelle de Paris em 1855 (Blanckaert, 1997). trata com desprezo a esposa, enquanto que o Iawoa, ao contrário, revela consideração para com as mulheres.

Note-se que o acadêmico francês chegou a tais conclusões pela leitura dos livros, sem ter se preocupado em indagar algo aos dois índios levados a Paris, os quais, entretanto, ele confirma ter "examinado". Passando aos aspectos físico-raciais, Serres afirmou que os Iawoa se assemelham aos escandinavos, enquanto que os Botocudo, com traços mongólicos que o surpreenderam, representam um "rebaixamento da raça americana”. Considerando a relação homem-mulher como um dos importantes parâmetros civilizatórios e acrescentando a este quadro as análises físico-raciais, Serres propunha que os Botocudo fossem estudados dentro da zoologia. Isto é, negava-lhes a condição humana. ${ }^{6}$

Neste ponto pediu a palavra um dos mais antigos membros da Academia, cujos cabelos brancos caídos sobre os ombros atestavam que ele não se enquadrava no padrão de comportamento da emergente burguesia parisiense, mas que pertencia à geração do Antigo Regime, da história natural ainda marcada pelo Iluminismo do século XVIII e contestada como descritiva e literária pela 'objetividade' dos novos cientistas da antropologia física. Era Auguste de Saint-Hilaire (1830) que, um quarto de século antes, estudara demoradamente os Botocudo e convivera com eles nos sertões do Brasil, e cujos trabalhos, então já publicados há mais de uma década, não mereceram citação no relatório de Serres.

Falando de improviso, Saint-Hilaire fez um breve resumo de seu contato com estes índios, defendendo-se, ressaltando que os analisara com todo cuidado e atenção de que era capaz. Sem polemizar de maneira contundente com Serres, Saint-Hilaire lembrou que seu principal auxiliar de pesquisas no Brasil durante cinco anos fora um índio Botocudo, Firmiano. E que também na mesma ocasião outro conhecido cientista e viajante, o russo Langsdorff, teve outro índio Botocudo como auxiliar nas pesquisas que realizou.

Mesmo sem explicitar, ficava a contestação: como tratar no campo zoológico seres humanos que revelavam inteligência considerável a ponto de serem não apenas guias, mas coadjuvantes das mais importantes expedições científicas da época? Percebe-se, sobretudo pelo que não foi dito, que Saint-Hilaire estava em conflito. Por um lado, ele se via impelido a reconhecer o valor e a importância cultural destes índios, com os quais adquirira conhecimentos. Por outro, via-se emudecido diante dos cânones da ciência e do progresso vigentes, que praticamente o impediam de formular estas proposições de maneira clara, sem cair em contradição com os conceitos de 'civilização' e 'barbárie' então vigentes.

Admitir elevado nível cultural de um Botocudo seria confrontar-se com as instituições culturais, religiosas, políticas e militares do Brasil ou da França. Assim, Saint-Hilaire parecia constrito entre os organismos aos quais pertencia e a grandeza dos conhecimentos que adquirira no 
${ }^{7}$ Os atuais estudos de antropologia biológica tendem a referendar a percepção esboçada por este cientista-viajante. Ver, por exemplo, a obra de divulgação de Langaney (1992).
8 'Ofício sobre a existência de índios Botucudo às margens do rio Doce', Revista do Instituto Histórico e Geográfico Brasileiro, (tomo 6, 1845). A mesma revista publicou a tradução do relatório de Jomard no tomo 9 de 1847. Era a 'descoberta' deste grupo indígena pelas elites letradas brasileiras. terreno. Saint-Hilaire também apontou, apenas à base da intuição e da observação empírica, a semelhança física entre estes grupos indígenas brasileiros e as populações orientais, especificamente chinesas. ${ }^{7}$

O caso destes dois Botocudo em Paris foi exemplar e interdisciplinar: além de fotografados e alvo de debates na Academia de Ciências, viram-se medidos, apalpados e tornados objetos de outros ramos das ciências. O clima de curiosidade em torno destes índios expressava significativa mistura de espetáculo atraente e seriedade científica: a tênue fronteira entre o exato e o exótico. De certa forma eram tratados como animais selvagens que precisavam ser melhor conhecidos. Causara sensação o primeiro gorila ‘descoberto’ pelos europeus na África em 1840... (Tinland, 1992).

Estes dois índios foram examinados também por uma comissão da Société de Géographie, cujo interesse principal, entretanto, foi de ordem lingüística (Jomard, 1846). Ou seja, foram extraídas (é o termo adequado) 194 palavras do idioma. Tal extração deu-se em várias etapas. Inicialmente, por Marcus Porte, classificado no relatório da Société como um viajante sem critérios metodológicos adequados para registrar um vocabulário. Devido a tal insuficiência, os membros da comissão encontraram-se pessoalmente com os dois índios para tirar dúvidas quanto a fonemas e significados das palavras, recomeçando o que foi chamado de interrogatório - exaustivo, pois incluía quase duas centenas de expressões.

Tal método de enquete foi explicitado por Jomard (1846), o membro da Société de Géographie encarregado de redigir o relatório: "Os viajantes devem se conscientizar de que há necessidade de interrogá-los sobre este ponto, retornando à carga repetidas vezes, para não se enganarem sobre a natureza da resposta."

Realçando o papel da insistência e de "retornar à carga" temos a relação entre ciência e poder, no ato mesmo do exercício científico e da relação entre entrevistadores e entrevistados. Tanto que o mesmo relatório termina com a recomendação de que tal vocabulário serviria para "ajudar os futuros viajantes em suas pesquisas, e mesmo servirlhes como poderoso auxiliar". Ou seja, integrava-se de maneira clara na perspectiva de produção de um saber científico por viajantes, tendo como meta uma conquista planetária do homem e da natureza pelos cânones da civilização européia ocidental (Pratt, 1999).

Tanto Serres quanto Jomard confirmam que estes dois índios identificavam-se como pertencentes a um grupo Naknyanúk e uma simples comparação do vocabulário recolhido na ocasião com outros vocabulários mostra que se trata da mesma língua dos demais grupos de Botocudo, apenas com pequenas variantes.

Coincidência ou não, os primeiros textos publicados por brasileiros e no Brasil sobre estas tribos de Botocudo só começaram a surgir em 1844, depois dessa exposição a que os dois 'espécimes' foram submetidos em Paris. ${ }^{8}$ Ou seja, após a ‘exportação’ de índios do território brasileiro, 
${ }^{9}$ Sobre a relação entre as culturas indígenas e os museus como instituições, ver o ensaio de Clifford (1992, pp. 81-101). vinha a 'importação', pelas elites letradas do Brasil, dos debates científicos e culturais elaborados a partir mesmo da presença de tais índios, num curioso caminho de dois sentidos. A peregrinação científica não parou por aí. Estes índios serviram ainda de modelos para portraits feitos por Werner e para a confecção de "moldes da cabeça e dos membros" que teriam sido guardados, junto com os daguerreótipos, na Galeria Americana do Muséum (Rey, 1880, p. 13).?

Na década de 1850 começou a ser organizada no Muséum d'Histoire Naturelle de Paris uma galeria especial, dedicada a colecionar reproduções de imagens 'naturais', como esqueletos, bustos moldados sobre corpos, reprodução em plástico de pés, mãos e órgãos, enfim, tudo que pudesse servir a um estudo comparativo entre as 'raças' humanas (Conduché, 1858). Era a chamada antropologia física incorporando as tecnologias mais atualizadas da época, a fim de obter as reproduções as mais 'realistas' possíveis. Dentro desta galeria, havia também 'desenhos naturais'. As primeiras fotografias que se incorporaram ao acervo do museu foram as dos esquimós e estas dos Botocudo. Os daguerreótipos provavelmente foram feitos em Paris. Não se sabe exatamente onde nem em que condições foram tirados, sendo desencontradas as informações sobre a data exata de sua aquisição pelo museu.

Percebe-se, assim, que tais imagens foram uma das peças-chave no momento de fixação de parâmetros científicos no campo do estudo das populações humanas. Estes dois índios, retirados da periferia e da floresta, estiveram no epicentro metropolitano das Luzes, como novos Jonas levados ao ventre do grande cetáceo de onde se geravam paradigmas que se espalhavam pelo mundo. Tudo sobre eles foi decodificado, dentro daqueles parâmetros do conhecimento, como que servindo de modelos vivos para uma tipologia de saberes institucionalizados.

Diante dos daguerreótipos, a pergunta, formulada pelo médico Phillipe Rey em 1878: o que foi feito destes índios depois de fotografados? Após terem sido descobertos, desapareceram sem deixar rastros. Mas de onde vem esta associação entre a objetividade rigorosa dos estudos de que foram objeto e a subjetividade quase sentimental da indagação sobre o destino individual deste homem e desta mulher fotografados? Talvez seja pelo deslocamento tão profundo a que foram submetidos, de tempo, espaço e cultura. Talvez por serem 'outros' que foram, de modo simbólico, antropofagicamente devorados por 'nós', depois de eternizados através da imagem.

Estes daguerreótipos não deixam de ser um ritual de sacrifício em nome de um progresso em torno do qual a percepção do século XXI mudou de maneira substancial. Talvez esta reaproximação entre observador e observado se deva também a uma subversão do significado através do signo, onde o olhar dos que foram fotografados passa a nos interrogar também. Tal movimento de interesse, de certo modo afetivo 
(que afeta), pode advir da constatação de que aprendemos 'muito' sobre aspectos lingüísticos, históricos, geográficos e culturais destes dois índios, mas nunca soubemos sequer seus nomes.

\section{A subversão das imagens ou o 'monólogo' do pesquisador}

Estas fotos podem ser vistas e interpretadas, trazendo à tona aspectos interessantes, objetivos e subjetivos. Mesmo sem palavras, elas apresentam elementos para compor uma narrativa histórica — história muitas vezes sem palavras escritas. Os sentimentos e dores que não cabiam nos parâmetros do discurso científico ressaltam nestas imagens mudas. Numa visão de conjunto, o que logo impressiona é o ar de tristeza, melancolia e abatimento que toma conta destes dois índios. Para o olhar de alguém do século XXI, é inevitável a comparação com prisioneiros dos campos de concentração: subnutrição (principalmente no homem) e flacidez (na mulher), um toque de resignação trágica, de raiva esmagada, de indignação contida e quase esquecida, um olhar entre mortiço e odiento, de quem ainda resiste mesmo sem forças para resistir. Um certo desprezo pelo interlocutor, cujo tom vem da altivez, da tradição da prática guerreira que, mesmo abafada pelas circunstâncias, persiste nestes índios como que enjaulados.

Os dois estão com o mesmo pano no colo, dobrado em posições diferentes. Este velho pano traz um toque 'civilizado' para a composição e serve para despojá-los mais do que para cobri-los. Os torsos estão nus. O homem veste uma calça branca e a mulher, algo que se parece com uma longa saia, indumentárias que devem ter sido impostas para a fotografia, a fim de camuflar a nudez. Os dois encontram-se sentados numa cadeira simples de madeira. O local das fotos era, portanto, algo equivalente a um estúdio, onde as pessoas fotografadas são enquadradas em determinada composição visual - haja vista o pano, o fundo neutro, a cadeira e a posição sentada. Não havia cenários exóticos de palmeiras ou vegetação tropical ao fundo, como era comum, inclusive para as fotos do imperador brasileiro Pedro II na mesma época. A intenção era o olhar científico, rigoroso, exato, implacável: são fotos que trazem a marca registrada do século XIX.

Não vou me deter aqui em um dos usos mais óbvios, ainda que importante, da chamada fotografia etnográfica, ou seja, comparar detalhadamente algumas características da cultura material com outras imagens, relatos e descrições, em relação ao colar, corte de cabelo, furo nos lábios etc.

Há duas imagens da mulher, uma de frente e outra de perfil (Figuras 1 e 2). Na primeira, ela fixa seu interlocutor, olha sem rodeios para o aparelho e para tudo que está por trás dele e seu olhar diz muito: denuncia sem palavras a violência. As mãos cruzadas placidamente no colo contribuem para um ar de resignação, de espera, mas ao mesmo tempo de harmonia — sem esquecer que são mãos vigorosas. Esta 
mulher, ainda jovem, transmite lucidez, serenidade, protesto indignado e aceitação trágica de seu destino. É uma verdadeira Gioconda dos trópicos, a nos desafiar com sua expressão ao mesmo tempo enigmática e contundente.

A circunferência do ventre, visível sob o pano, e o volume dos seios indicam alguma relação com maternidade. ${ }^{10}$ Estaria grávida ou parira

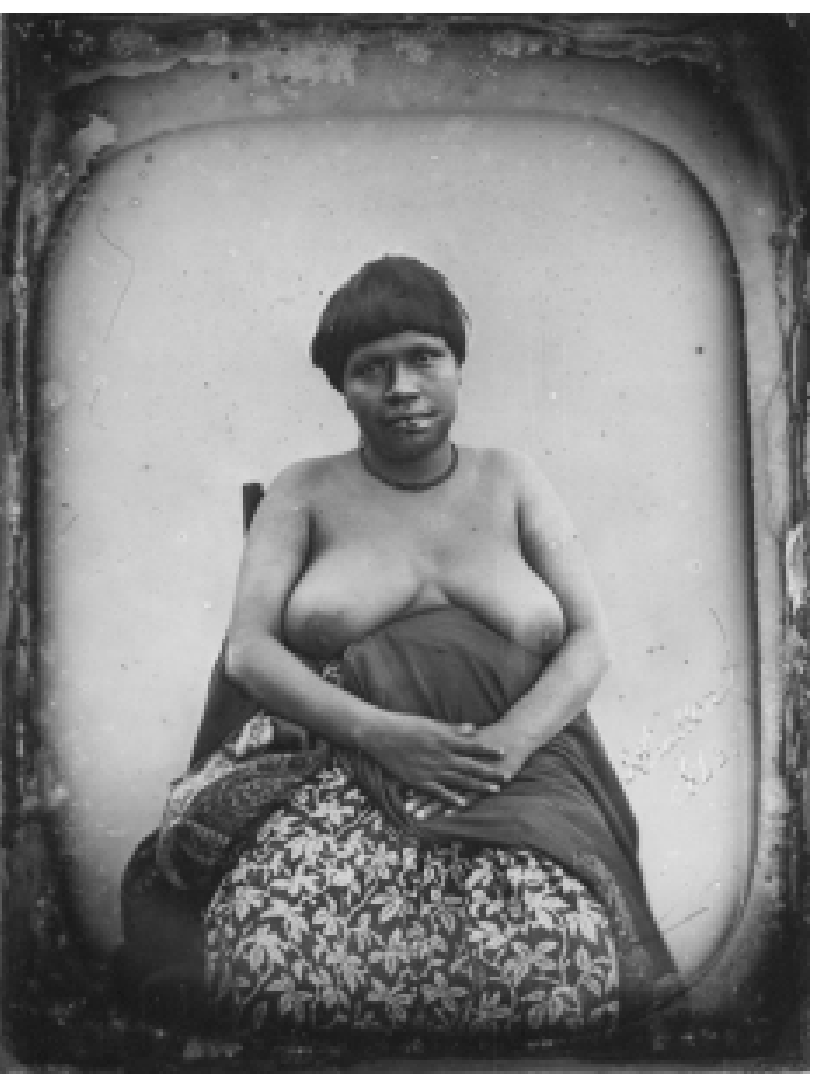

Figura1 - Daguerreótipo D 801319 (Musée de L'Homme, Paris).

${ }^{10}$ Pode-se perceber isso também na foto D 80 1318, em que ela aparece de lado.

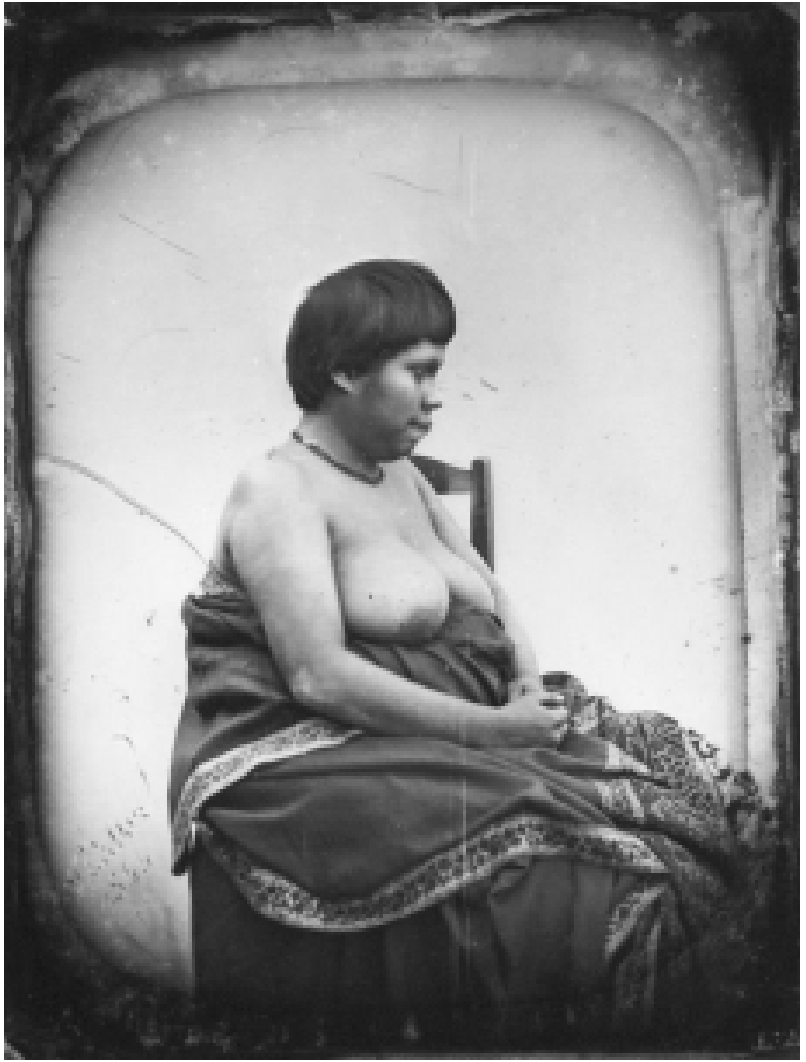

Figura 2 - Daguerreótipo D 801318 (Musée de L'Homme, Paris).

recentemente? Haveria uma criança implícita na foto? A espessura dos lábios um pouco aumentada e o matiz de docilidade em sua expressão associam-na com o lado feminino e materno, caracterizando seu potencial de delicadeza.

As fotos desta índia nos revelam ainda algumas pistas, digamos, materiais. O corte dos cabelos, o colar, o furo no lábio inferior, onde antes devia estar o botoque, indicam que ela nasceu nas selvas, no meio de uma tribo. O vigor e a densidade do olhar da mulher nos levam a indagar se ela não seria também um tipo de xamã de seu grupo, tendo desenvolvido sensibilidade mística.

Estabelecendo uma espécie de monólogo diante dos daguerreótipos, pergunto até que ponto é possível chegar ao diálogo. Trata-se de fronteira 
arriscada para ser transposta. Às vezes, quando encaro a imagem desta mulher de 1844, tenho a impressão de receber um olhar levemente irônico e superior, como se ela estivesse relativizando o sofrimento pelo qual passava. Em outros momentos, parece-me que a índia fotografada sabe o tamanho da onda que se abateu sobre ela e seu povo e exprime melancolia dolorida, acompanhada de um certo ar de raiva e desafio. A aparência triste reforça a constatação de que a mulher foi arrancada de seu modo de vida original e que se encontra num lugar estranho já há algum tempo e, por isso, tal expressão facial pode ser considerada também como uma 'prova material'. Tal 'melancolia dos selvagens' já fora notada no século XIX, mas em geral era explicada por fatores climáticos, atávicos e raciais — nem sempre percebida como resultado da condição social de desenraizamento que poderia causar distúrbios psíquicos, em parte conhecidos hoje como depressão.

Percebo como historiador que esta índia deixou com seu silêncio vibrante e na força de seu olhar a marca de um testemunho mais eloqüente do que a maior parte dos textos que haviam sido escritos até então sobre estas tribos. Uma flecha que atravessa os tempos com docilidade, um vigor que incomoda, expressando algo que só aqueles que foram muito oprimidos (mas não se deixaram abater totalmente) sabem mostrar. Diante do naufrágio pessoal e da coletividade, ela parece reunir todo sofrimento, solidão e colocá-los, como oferenda, na expressão do rosto eternizada nesta imagem.

O rapaz, de calças brancas, parece ser ainda mais jovem, um adolescente (Figura 3). Magro, com os ossos do tórax salientes, mantém um certo vigor físico, de quem foi musculoso. Embora esteja de frente, manteve as pálpebras semicerradas no momento da foto, o que lhe dá uma aparência fugidia, esquiva. Parece ter engolido todo sofrimento e não espera mais nada de ninguém. Ainda guarda uma certa altivez, quase apagada num rosto endurecido pela raiva muda. Sua face parece talhada em pedra, numa desolação que não se desmanchará jamais, como se não quisesse mais viver ou olhar em volta, embora seu caráter, no fundo, pareça permanecer intacto. Diversos depoimentos em outras ocasiões falam de índios Botocudo que, quando aprisionados, deixam de comer ou falar, definham e acabam morrendo.

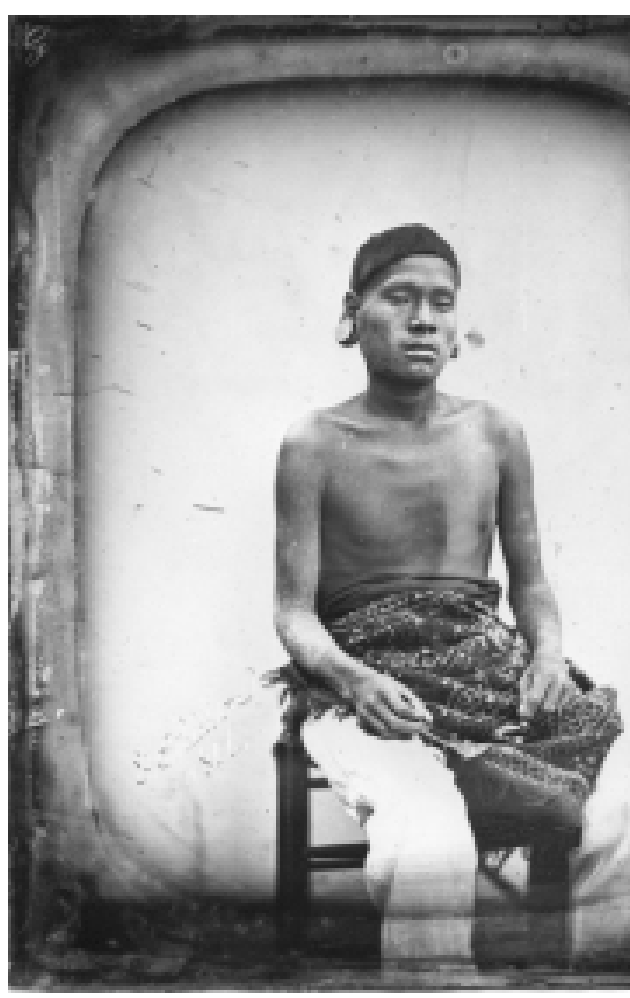

Figura 3 - Daguerreótipos D 801320 e E 79 1396 (Musée de L’Homme, Paris). 
Este jovem pode ter sido um desses incontáveis casos de martírio anônimo. Ele ainda tem os botoques circulares nas orelhas e o cabelo cortado à moda de sua tribo.

Com a mão esquerda estendida sobre o colo e a mão direita fechada, (Figura 4), o rapaz aparece 'de três quartos'. As manchas na pele da face, braços e tórax indicam que estava doente. Sua magreza é ainda mais acentuada, os ossos do peito, da clavícula e costelas à mostra sob a pele. Pelo tamanho das mãos percebe-se que era (ou se tornaria) alto. Nas três fotos em que aparece, seu rosto expressa raiva e revolta nítidas. 'De três quartos', os olhos mortiços parecem ao mesmo tempo arregalados e fulminantes. Tentando reconstituir, a partir destas expressões, sua recente trajetória de vida, já mencionada nos documentos textuais que dão conta de sua remessa para a França, vemos que ainda não teve tempo de se conformar com os reveses, nem pretende se aquietar. A imagem de perfil (Figura 5), com o pescoço virado bruscamente, dá a impressão de que oferece a cara a tapa, como para evidenciar a violência que sofria. O corte de cabelo e os botoques nas orelhas confirmam também que ele vivia na selva, no meio de uma tribo, antes de ser retirado do seu meio.

Recentemente encontrei, entre os índios Krenak, rapazes cujos traços fisionômicos se assemelham aos deste índio. Tal observação também

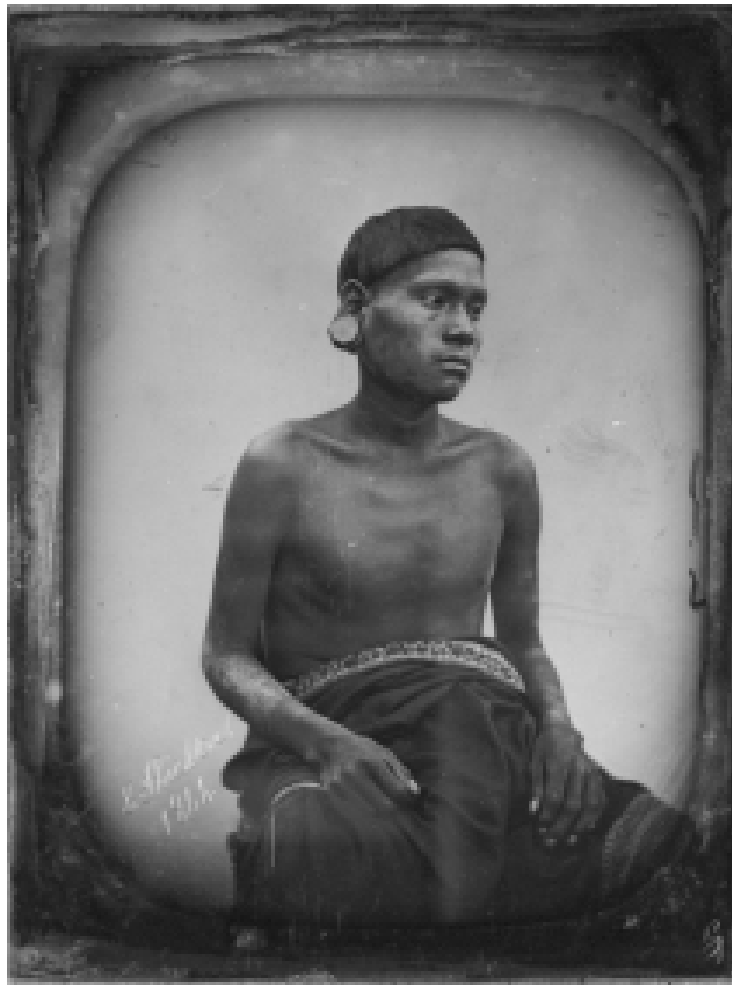

Figura 4 - Daguerreótipos D 801320 e E 79 1397 (Musée de L’Homme, Paris).

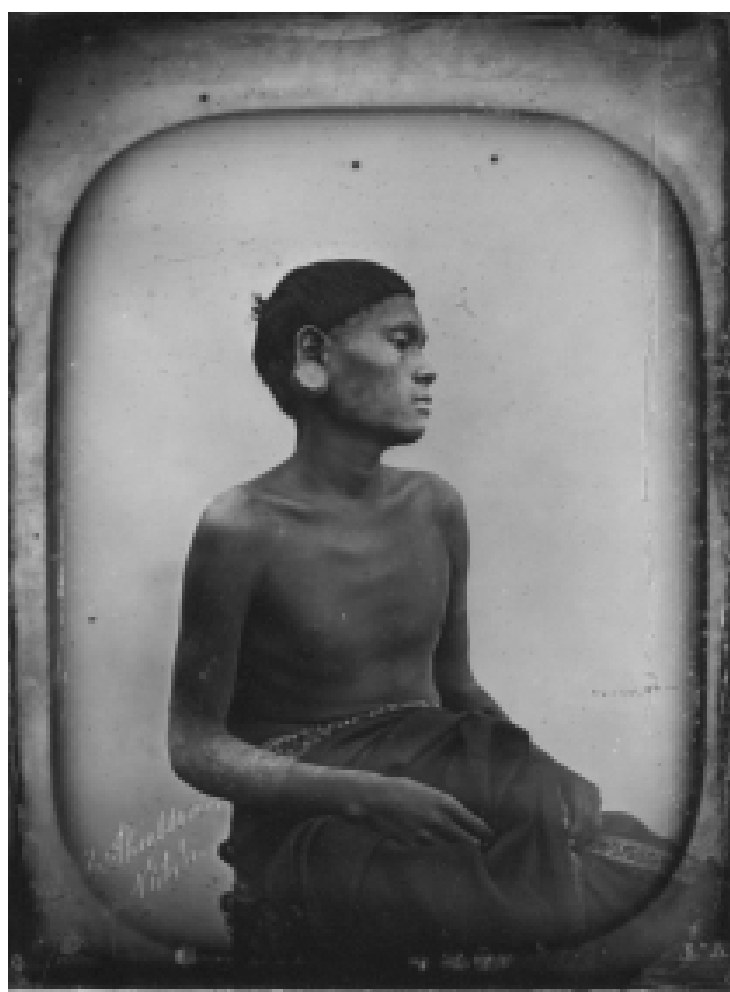

Figura 5 - Daguerreótipo E 801317 (Musée de L'Homme, Paris). 
afetou-me, como se o personagem da foto retornasse à vida ou, mais simplesmente, como se os jovens desse grupo retomassem a vida de seus antepassados, num jogo universal de mudanças e permanências entre as gerações, o que não é característico somente entre os chamados grupos indígenas.

Mais do que um registro neutro ou 'real', estes daguerreótipos trazem em si uma carga civilizatória. Mesmo que a intenção inicial dos detentores das imagens fosse fazer estudos 'raciais' ou 'científicos', as expressões de sentimentos e condições de vida destes índios assim registradas e cotejadas com outras fontes documentais são também significativas. Abandonando a condição de cobaias, estes índios se expressaram através do registro de suas aparências. Como se os objetos fotografados se apropriassem da imagem e subvertessem seu significado, criando outros discursos não verbalizados que transcendiam o movimento de fixação, conhecimento e controle contido no ato de fotografar. À sua maneira, estes dois índios posaram, responderam, exprimiram com seu corpo tudo aquilo não revelado por suas vozes. Eles não foram apenas 'descobertos', mas descobriram a fotografia e elaboraram seu discurso, contaram sua história, ainda que sem palavras.

Muitos fatores convergiram para que estas fotografias fossem realizadas. Elas sinalizam uma evolução tecnológica da civilização ocidental e que foi possível levar tais recursos até estes índios. Indicam, portanto, que estes não tinham condições de responder pela guerra, pois estavam sendo derrotados neste campo: guerra e imagem não deixam de estar interligadas. Depois do relâmpago dos fuzis e das facas, vieram as luzes das ciências e logo era a composição química das câmeras obscuras que agia diante dos índios. Os guerreiros Botocudos finalmente fotografados. Esfinges captadas pela tecnologia e decifradas pela racionalidade científica, suas imagens guardam intacta a opressão a que foram submetidas.

Tão diferentes da imagem mítica ou romântica do 'homem novo americano', tão distintos das alegorias patrióticas indianistas em voga nas Américas do século XIX, estes índios retratados tampouco apresentam a expressão feroz de canibais devoradores, presente na maioria dos relatos escritos sobre eles até aquela época. De certa maneira, este homem e esta mulher, ainda que classificados pelo membro da Academia de Paris no campo da zoologia, parecem nos dizer que seus 'espíritos' e seus corpos estavam irremediavelmente aprisionados ali, no momento em que se realizou diante deles a alquimia dos daguerreótipos.

\section{Diálogos: escambo das imagens}

Para se ir atualmente do Rio de Janeiro ao território dos Krenak, não é mais necessário organizar expedições demoradas, acidentadas viagens durante semanas, como no tempo dos primeiros viajantes do século XIX. O trajeto pode ser percorrido de carro em 12 horas por vias 
${ }^{11}$ Entre os dias 8 e 12 de setembro de 1998 e 4 e 8 de fevereiro de 2000 estive entre os Krenak, com o objetivo de colher dados para a pesquisa histórica que realizo.

12 "Mostre suas fotos a uma pessoa; ela imediatamente lhe mostrará as dela" (Barthes, 1980, p. 16). asfaltadas em condições razoáveis. Da beira da estrada até a área indígena há uma trilha de terra de uma dezena de quilômetros, também acessível a veículos motorizados, no município de Resplendor, Minas Gerais, região Sudeste do Brasil. Cerca de duzentos Krenaks vivem numa área de quatro mil hectares, da qual somente obtiveram a posse definitiva em 1997 — pálida lembrança do tempo em que habitavam vasta extensão do território entre os rios Doce, Jequitinhonha e Pardo.

A atual reserva fica às margens de um trecho do rio Doce, área tradicional do tempo em que eram chamados de Botocudos, mas ocupa uma ínfima parcela em relação ao que possuíam antes. Seus habitantes vivem da agricultura, pecuária ou de pequenos empregos na cidade vizinha e, na maneira de se vestir e nos hábitos alimentares, não se distinguem do restante da população rural da região. Alguns fazem artesanato (colares, pulseiras, zarabatanas, arco e flecha etc.) para vender em encontros dos movimentos indígenas, para visitantes ou mesmo para usar em algumas cerimônias que começam a ser retomadas. Em algumas casas (típicas do modelo nacional) há antenas parabólicas para televisão; em outras, a situação de miséria é mais evidente.

São pobres e culturalmente distantes das cidades vizinhas, embora as freqüentem com regularidade, especialmente os mais jovens. A altivez e o orgulho são marcas registradas nos comportamentos. Falam todos o português, mas também a língua Krenak, fluentemente, sobretudo entre os mais velhos. Têm plena consciência de sua especificidade cultural e de seu passado histórico no interior da sociedade brasileira e são juridicamente reconhecidos como tal pelo Estado nacional, apesar de terem sido dados como extintos oficialmente entre 1950 e 1970.

Desde que eu começara a pesquisar a história destes índios, durante cerca de cinco anos, conhecia-os apenas através de relatos e imagens, sobretudo do século XIX. Quando fui ao território dos Krenak, levei imagens do seu grupo étnico do século XVI ao XX para mostrar-lhes, sendo que na mais recente carreguei também as reproduções dos daguerreótipos de 1844 que obtive no Musée de L'Homme. ${ }^{11}$

Um dos meus 'informantes' (para utilizar o jargão etnográfico) foi José Alfredo de Oliveira, 54 anos, apelidado de 'seu' Nego, reconhecido em geral como cacique, cujo nome na língua Krenak é Him (com o 'h' aspirado). Sentei-me na velha poltrona de sua sala e mostrei-lhe algumas reproduções de imagens antigas, dos séculos XIX e XX. Ele olhou tudo com muita atenção, identificou, nos registros mais recentes, rostos de parentes e conhecidos. Em seguida, levantou-se e voltou de seu quarto com uma batelada de pequenos álbuns e envelopes de fotos que passou a me mostrar também. O gesto, aparentemente banal, pareceume importante por vários motivos. ${ }^{12}$ Quando visitamos parentes ou amigos, existe o hábito de olharmos e trocarmos fotos. Mas a troca que 
começava a se estabelecer ali era diferente, pois estávamos nos vendo pela primeira vez, apenas depois de alguns instantes.

Como historiador, conhecera os índios de 'papel velho', ou melhor, as marcas deixadas pela presença e ação dos índios em diferentes documentos, embora histórias as mais vibrantes compusessem os textos e ícones. E uma das minhas formulações centrais para buscar compreender a trajetória deste povo era justamente a de que o contato com os homens da ciência e dos intelectuais letrados (e respectivas produções) foi uma das formas mais eficazes no processo de dominação intentado sobre estes grupos.

Constatar agora que uma de suas lideranças tinha também seu próprio acervo de imagens, de ícones fotográficos, ganhava uma dimensão literalmente significativa (Freire, 1999, pp. 9-36). Como se a resistência tivesse se estendido do campo propriamente bélico, guerreiro ou cultural, para a disputa também no campo simbólico. E realmente 'seu' Nego tem esta prática reconhecida no interior do grupo: recolhe fotos de família, pede a visitantes que tirem retratos registrando momentos importantes, cobra o envio destas fotografias, guarda-as cuidadosamente. Não são apenas cenas domésticas, mas também uma verdadeira galeria de registros sobre a luta pela posse da terra das últimas duas décadas, da qual ele participou ativamente: instantâneos de encontros com autoridades, de reuniões de lideranças indígenas. Sua voz engasga um pouco de emoção ao mostrar o retrato (tremido no foco e já desbotando) com a cena do despejo forçado que sofreram, quando foram arrastados de suas terras por soldados durante a ditadura militar no Brasil na década de 1970 .

Depois de ter conhecido grande parte do aparato científico e cultural produzido ao longo de cinco séculos sobre este grupo indígena, eu deparava ali - no interior daquela área em cuja entrada uma placa oficial assinala que se trata de território indígena - com aqueles papéis guardados em envelopes de fotografias e que representam, de alguma maneira, a formação por este chefe Krenak de um 'aparato' próprio de memória, através de imagens não apenas orais ou artesanais, mas apropriando-se, dentro de suas possibilidades, das mesmas técnicas utilizadas sobre este grupo (tecnologia que fora inventada com o daguerreótipo).

Mostrei os daguerreótipos de 1844 para 'seu' Nego, explicando em poucas palavras o significado que atribuo a tais imagens: onde as encontrei, sua antiguidade etc. Eu havia mostrado antes os daguerreótipos de botocudos feitos por Marc Ferrez em 1876 e ele, rindo, não aceitou identificar-se com os índios ali retratados, indicando que deveriam ser de outra etnia. Mas, diante das imagens de 1844, sua atitude foi diferente. Olhou longamente, uma por uma, em silêncio. Repetiu a operação várias vezes, sentado na varanda de sua casa com ampla vista sobre a área Krenak.

Deixei-o observar o material e trouxe mais algumas informações que recolhera em arquivos, como a recomendação de que aquele casal 
deveria ser estudado na zoologia, como bichos. Neste ponto ele interrompeu a observação das fotos e comentou, com uma leve risada irônica: "Até hoje o povo considera os índios como bicho... hé!..." Momento de silêncio; olhou de novo as fotos, detendo-se na do rapaz que está 'de três quartos'. E continuou: "Não têm assim confiança nos índios como gente, né? Eles acham que os índios é... bicho do mato... hé!...”, com riso novamente curto e irônico.

Pausa. Retomou a conversa, mas agora deixando de olhar as fotos à sua frente e virando de lado o rosto e o corpo em direção ao exterior, à ampla área a sua volta, com árvores, rio, colinas, vale e montanhas na linha do horizonte. "Até agora mesmo eles mataram muito índio guerreando... Tem um caso que contam que, ali, embaixo (aponta) mataram ele na prisão, os brancos mataram ele.'

A conversa foi longa e a partir dali o chefe Him não mais olhava para as fotos à sua frente, mas vagueava o olhar pelo território ao redor enquanto falava, embora umas duas vezes tenha recorrido à consulta de fotos antigas para exemplificar o que dizia. A propósito do aspecto doente do rapaz do daguerreótipo, ele denunciou as precárias condições de saúde dos atuais índios: a Funai (órgão do governo federal responsável pelos índios no Brasil) não tem dado a devida assistência médica aos Krenak. Uma simples consulta ou compra de medicamento requer grandes esforços e deslocamentos sem nenhum apoio, disse ele.

As fotografias puxaram o fio da memória, interligando também diferentes tempos. 'Seu' Nego lembrou de um episódio na década de 1970, quando militares ocupavam a área indígena e proibiam os moradores de falarem em suas línguas originais. "Os índios não podiam conversar na língua, eles mandavam prender, mandavam bater... Não sei não... nós vivemos uma vida muito triste. Eu mesmo fiquei preso 17 dias, só porque desobedeci às ordens da polícia e atravessei para o outro lado do rio sem pedir ordem deles."

Com este depoimento, percebi que começava a realizar uma troca ou escambo de imagens, em diferentes dimensões, a começar pela mostra recíproca de fotografias e reproduções antigas. Como também por um certo intercâmbio de informações que cada um trazia: eu, como pesquisador, da investigação nos arquivos e de minhas hipóteses; ele, como personagem, de suas vivências e reflexões. Os daguerreótipos e o desejo de cada um de falar, a partir daqueles retratos, funcionaram como catalisadores de expressões diferentes sobre uma mesma temática, que é a história daquele grupo indígena. Seria possível sintetizar minha percepção deste amálgama, onde cada um guardou sua especificidade, mas esteve atento ao que o outo trazia?

'Seu' Nego trouxe até a atualidade algo que a princípio eu tomava como típico sobretudo do século XIX: a animalização dos índios. Associou imediatamente a guerra e a repressão militar àquelas imagens; falou do ar de tristeza (que aparece também em sua própria fisionomia) e de suas motivações social e historicamente situadas. Deixou entrever 
riso irônico e sutil diante de situações dramáticas, que me fez lembrar a expressão da índia do retrato. Mostrou-me seus dois arquivos: o de imagens fotográficas e o da memória pessoal como pertencente a uma coletividade com identidade própria.

Os daguerreótipos de 1844 representaram, de certa maneira, uma das 'descobertas' da fotografia em relação aos índios. Ao 'descobrir' ele próprio estes daguerreótipos, o chefe Him deu-lhes um sentido dentro da história de seu grupo e de sua própria história pessoal. Eu, como historiador, pude olhar e de alguma maneira interferir nestas duas 'descobertas' e fazer as minhas próprias, tanto dos retratos antigos, como dos Krenak de hoje, num entrelaçar de tempos e olhares que não é linear e que pode se desdobrar ao infinito.

Mostrei também os daguerreótipos a uma índia Krenak, Djanira de Souza, 47 anos, tratada pelo apelido de Deja, na língua Krenak chamada Indjambré. Vivaz, ela é chefe de um grupo familiar no interior da aldeia, composto de muitos filhos e netos. Conhecida como contadora de histórias, tem fluência verbal e é uma das depositárias da tradição oral das lendas e narrativas antigas. Orgulha-se de ser bisneta do 'capitão' Krenak, chefe indígena que deu o nome atual deste grupo étnico.

Recebeu-me no terreiro de sua casa e logo formou-se à volta um grupo de familiares para escutar a conversa, jovens e crianças. Todos sentaram-se no chão; só havia duas cadeiras e ela, sentando-se numa, designou-me a outra, tratando-me de maneira fidalga por kraí, branco ou não-índio no idioma Krenak. Mostrei-lhe as reproduções dos daguerreótipos e repeti minha breve explicação sobre elas. A reação de Deja foi imediata: passou a mostrar o retrato da mulher aos filhos e netos ao redor, fazendo a seguir comentários sobre cada uma das imagens na sua língua. Como não compreendo Krenak, aguardei. Mostrando o retrato do rapaz posando de frente, ela passou a falar em português, ou seja, para mim também: "Olha aqui, os parentes da gente!"

Com esta simples frase, Indjambré estabeleceu o parentesco e a descendência, pouco importando se genética (consangüínea), cultural (do mesmo grupo etnolingüístico) ou simbólica (identificando a si e a seu grupo com os dois índios fotografados). As imagens feitas em Paris em 1844 estavam sendo repatriadas. Ainda brandindo o retrato do rapaz, ela afirmou: "Esse aí já morreu há muitos anos, né?... Ave Maria! Nós somos os restantes, né?"

E Dejanira voltou a falar apenas em krenak com seus próprios descendentes, fazendo, entre outras coisas, comentários sobre o botoque nas orelhas do rapaz e no furo dos lábios da moça, como me traduziria rapidamente depois. Mas, falando em sua língua original, ela estava como que estabelecendo o vínculo entre os antigos e os novos. Naquele momento, dei-me conta de que meu papel de historiador em fase de pesquisa junto a estes índios seria exatamente este: como um agente transmissor entre determinados arquivos (aos quais eles não costumam 
${ }^{13}$ Posteriormente recordei-me do texto sobre o "riso dos selvagens", de Lestringant (1994, pp. 15-40). ter acesso) e o patrimônio de sua cultura, que não é estática e pode se reelaborar, inclusive, neste contato com o passado do grupo, desde que tal transformação seja, digamos, filtrada por seus próprios valores e concepções, que se expressam sobretudo através da identidade lingüística. Talvez por isso, no momento crucial de transmitir aos seus descendentes a imagem de antepassados, simbólicos ou não, ela tenha feito questão de se expressar na língua Krenak. Enquanto falava, ela deu uma gargalhada, no que foi acompanhada de seus parentes. Eu mesmo acabei rindo também. Ela regozijou-se, em português: "Ah, uma risada...!"13

Em seguida, Deja perguntou-me, sempre mostrando as fotos erguidas, se foram tiradas nos tempos do SPI (Serviço de Proteção aos Índios, órgão criado pelo governo republicano brasileiro em 1910). Vacilei um pouco para pronunciar-me e ela não aguardou minha resposta: deu o silêncio como assentimento e passou a falar dos tempos antigos, isto é, aqueles alcançados por sua memória pessoal ou transmitidos a ela por seus antepassados imediatos: "Isso aqui tudo era mata... Depois que o branco andou matando índio..."

Em duas frases ela estabeleceu a ligação entre a destruição do meio ambiente com a perseguição aos grupos indígenas, trazendo também a associação entre guerra e imagem. Sua narrativa passou a ser acompanhada de expressiva linguagem corporal. A gesticulação traçou arabescos no ar; a cabeça volveu-se constantemente de um lado para outro, de maneira pausada e segura, querendo mostrar o lugar onde se passou a história que contava. Os dedos apontando e os braços esticados pareciam querer tocar ou trazer de volta o tempo passado, revivido de maneira intensa através de suas palavras. Mais uma vez a linearidade do tempo rompia-se, enquanto se construíam os nexos entre aqueles daguerreótipos e o tempo presente. Os dedos e mãos de Indjambré, movendo-se no ar, iam tecendo essa teia.

Ao falar da ligação entre fotografia e morte, Barthes (1980, p. 25) lembrou o exemplo da Comuna de Paris, quando os revoltosos que se deixaram fotografar foram depois perseguidos pela polícia de Thiers e assassinados. Agora vejo Indjambré narrar-me, sempre empunhando as reproduções dos daguerreótipos (apropriara-se deles) e às vezes esgrimindo-as no ar, uma história contada por seu pai, que era pequeno quando o episódio ocorreu. Foi uma matança de quase toda uma aldeia por 'brancos' (krai). Numa primeira investida, os agressores mataram alguns adultos e levaram todas as crianças. Em seguida, deixaram as crianças (que choravam alto) na beira da estrada e esconderam-se nas proximidades. Quando os pais, ouvindo o choro, apareceram para resgatar os filhos. foram mortos a golpes de facão. "Se não aparecia ninguém, eles cortavam os nenenzinhos de facão também, mataram tudo."

Ela contou então, sem esconder satisfação, como os sobreviventes do massacre, entre os quais seu pai, juntaram-se a outra tribo e também, 
ao que parece, a alguns policiais e, depois de muitas artimanhas e esforços, conseguiram vingar-se, matando também a facadas os brasileiros que haviam cometido a agressão. E arrematou: "Nós sofremos e estamos sofrendo até agora. Não matou a gente porque nós fugimos."

Mas em seguida abriu um sorriso e num gesto largo à sua volta disse: "Esse povo aqui todo é meu, isso tudo aqui é filho, neto..." Completava-se em sua narrativa o ciclo vital e o sentido do tempo. As imagens do passado, percebidas no presente, reavivaram a memória dos massacres e da guerra, mas, ao encerrar sua narrativa, ela apontou para o seu futuro, sua descendência. Os que sobreviveram e sobrevivem às tentativas de extermínio físico ou cultural. Os que escaparam das lentes dos daguerreótipos e dos golpes dos facões. Em seu relato também apareceu de forma vigorosa aquilo que chamei de relação entre guerra, expansão da civilização ocidental de matriz européia e imagem.

Comparando o diálogo com Him à narrativa bilíngüe de Indjambré, remeti-me novamente aos daguerreótipos, aos 'papéis velhos' dos arquivos e às marcas deixadas neles por índios que já morreram. Nas imagens de 1844, a mulher olha de frente e o rapaz, esquivo, exprime sua revolta repudiando o contato. Este grupo indígena, diversificado e numeroso em tempos passados, caracterizou-se, entre outras coisas, por ser composto de grandes estrategistas, neste contato de longa duração com os kraí. Predominava entre alguns uma atitude de convivência de fronteiras e interação como forma de sobrevivência, enquanto que em outros aparecia mais a defesa da integridade cultural e de distanciamento no contato como atitude de resistência. Guerreiros ambos, mas de maneira diferente.

Ao dirigir-me até os Krenaks, eu já havia formulado, a partir de outras referências, que não se deve esquecer que o objeto fotografado também se transforma em sujeito e, através da pose e de expressões não-verbais, pode dar seu recado. Entra também o olhar de quem vê a foto. Mas para um historiador, ligado sobretudo ao século XIX, ver os seus personagens adquirirem vida é algo perturbador. Não creio estar incorrendo no pecado mortal do anacronismo ao fazer esta afirmação, nem projetando em pessoas contemporâneas atributos que não pertecem a elas (Farge, 2000). Mas, afinal, havia mesmo uma ligação entre guerra, imagem, civilização ocidental, ciência e (acrescento) expansão nacional. Havia e há. O elo entre os daguerreótipos e os atuais habitantes desta margem do rio Doce foi estabelecido também por eles próprios.

Um passo importante é reconhecer que as heranças guerreiras e culturais não pertencem apenas aos índios - e ambas são muitas vezes negadas pela sociedade brasileira. E então impõe-se o desafio de compreender este processo que já dura cinco séculos no contato entre os povos indígenas - que, enquanto sujeitos históricos, transformamse historicamente ou se transfiguram etnicamente, mas nem por isso desaparecem - e a nacionalidade predominantemente opressora e destruidora das pluralidades. 
Os historiadores por muito tempo contribuíram e contribuem ainda para a opressão sobre os índios, mesmo sem se relacionarem diretamente com tais grupos, mas gerando imagens, criando, reforçando e divulgando estereótipos e preconceitos ou simplesmente calando-se sobre o tema. E, talvez na perspectiva atual, a contribuição dos historiadores - espécie de arqueólogos de artefatos simbólicos, impressos ou verbais, ou como antropólogos de um diálogo entre o passado e o presente de culturas diferentes — esteja apontada neste cruzamento de olhares, que não se confundem, mas que se interligam na construção da trama histórica, enfocando os índios não como objetos, mas como sujeitos históricos.

Os atuais Krenak não indagaram sobre o destino dos índios fotografados em 1844: eles mostraram e contaram o que restou vivo deles.

\section{REFERÊNCIAS BIBLIOGRÁFICAS}

Barthes, Roland

1980

Blanckaert, Claude 1997

Bonte, Pierre e Izard, Michel (orgs.)

1992

Clifford, James 1992

Conduché, M. E. 17.4 .1858

Farge, Arlette 2000

Freire, José Ribamar Bessa (org.) 1999

Freire, José Ribamar Bessa (org.) 1996

Frizot, Michel 1994

Garrigues, E.
La chambre claire. Note sur la photographie.

Paris, Cahiers du Cinéma/Gallimard/Seuil.

'La création de la chaire d'anthropologie du Muséum dans son contexte institutionnel et intellectuel (1832-1855)'. Em C. Blanckaert; C. Cohen; P. Corsi e J. L. Fischer (orgs.), Le Muséum au premier siècle de son bistoire. Paris, Ed. du Muséum d'Histoire Naturelle.

Dictionnaire de l'ethnologie et de l'anthropologie.

$2^{\mathrm{a}}$ ed., Paris, PUF.

'Muséologie et contre-histoire. Voyages sur la Côte Nord-Ouest'. Révue d'Histoire et d'Archives de l'Anthropologie. Paris, Séction Histoire de l'Ethnologie du Musée de l'Homme, 11, pp. 81-101 (trad. de Maria Helena Cardoso de Oliveira e José R. Bessa Freire, Cadernos de Etnomuseologia, $\mathrm{n}^{-}$1, Programa de Estudos dos Povos Indígenas, Universidade do Estado do Rio de Janeiro, 1999, pp. 37-76).

'La photographie au Muséum d'Histoire Naturelle'. La Lumière - Revue de Photographie. Paris, nำ 16.

La chambre à deux lits et le cordonnier de Tel-Aviv. Paris, Seuil.

'A descoberta do museu pelos índios'. Cadernos de Etnomuseologia, no 1, Programa de Estudos dos Povos Indígenas, Universidade do Estado do Rio de Janeiro, pp. 9-36.

Os índios em arquivos do Rio de Janeiro.

Rio de Janeiro, Programa de Estudos dos Povos Indígenas/SR-3/UERJ, 2 vols.

'Corps et délits. Une ethnophotographie des différences'.

Em Nouvelle histoire de la photographie. Paris, Adam Biro, pp. 259-71.

'Le savoir ethnographique et la photographie'.

L'Ethnographie, no 109 , Paris. 
Jomard

nov.-dez.

1846

Langaney, André

1992

Lestringant, Frank 1994

Mattos, Izabel Misságia 1996

Opptiz, M.

1992

Paraíso, Maria Hilda B. 1998

Pratt, Mary Louise 1999

Rey, Phlippe-Marius 1880

Saint-Hilaire, Auguste de 1845-46

Saint-Hilaire, Auguste de 1830

Scherer, Joanna

1996

Serres, M.

1845-46

Starl, Tim

1994

Tinland, Frank

1992

Wied-Neuwied,

Maximilien

1821-22
'Notes sur les botocudos'. Extrait du Bulletin de la Société de Géographie.

Paris, Société de Géographie.

Tous parents, tous différents.

Paris, Chabaud/Muséum National d'Histoire Naturelle/Musée de l'Homme.

'Léry ou le rire de l'Indien'. Prefácio. Em Jean de Léry,

Histoire d'un voyage en terre de Brésil (1578).

Paris, Le Livre de Poche. Bibliothèque Classique.

'Borum, bugre, kraí. Constituição social da identidade e memória étnica krenak'. Dissertação de mestrado, Belo Horizonte, Faculdade de Filosofia e Ciências Humanas da Universidade Federal de Minas Gerais.

'Anthropologie visuelle'. Em Pierre Bonte e Michel Izard (orgs.),

Dictionnaire de l'ethnologie et de l'anthropologie. $2^{\underline{a}}$ ed., Paris, PUF, pp. 742-3.

'Os botocudos e sua trajetória histórica'. Em Maria Manuela

Carneiro da Cunha (org.), História dos índios no Brasil. $2^{\underline{a}}$ ed, São Paulo, Companhia das Letras, pp. 413-30.

Os olhos do império: relatos de viagem e transculturação.

Bauru, Edusc.

Étude anthropologique sur les botocudos.

Paris, Octave Doin Éditeur.

'Sur la ressemblance, dans la conformation physique, des Chinois et des Indigènes brésiliens'. Comptes rendus hebdomadaires des scéances de l'Académie des Sciences, Paris, tomo 21, juil.-déc. 1843, pp. 4-10.

Voyage dans les provinces de Rio de Janeiro et de Minas Geraes.

Paris, Grimbert et Dorez, tomos 1 e 2 .

'Documento fotográfico: fotografias como dado primário na pesquisa antropológica'. Cadernos de Antropologia e Imagem, n ㄱ, Rio de Janeiro, Núcleo de Antropologia da Imagem, Universidade do Estado do Rio de Janeiro, pp. 69-83.

'Étude de la race américaine. M. Serres présente les portraits photographiques de deux indigènes du Brésil appartenant à la tribu des botocudos'.

Fotos de M. Thiesson. Comptes rendus hebdomadaires des scéances de l'Académie des Sciences, Paris, tomo 21, juil.-déc. 1843, pp. 5-11.

'Un nouveau monde d'images. Usage et diffusion du daguerréotype'.

Em Michel Frizot (org.), Nouvelle histoire de la photographie. Paris, Adam Biro.

'Les limites de l'animalité et de l'humanité selon Buffon et leur pertinence pour l'anthropologie contemporaine'. Em Ernst Mayr (org.), Buffon 88 - Actes du Colloque International. Paris.

Voyage au Brésil, dans les années 1815, 1816 et 1817, par S. A. S. Maximilien, prince de Wied-Neuwied. Paris, Arthus Bertrand, 3 vols.

Recebido para publicação em outubro de 2000.

Aprovado para publicação em maio de 2001. 